\title{
CDC73 Gene Mutation
}

National Cancer Institute

\section{Source}

National Cancer Institute. CDC73 Gene Mutation. NCI Thesaurus. Code C43375.

A change in the nucleotide sequence of the CDC73 gene. 